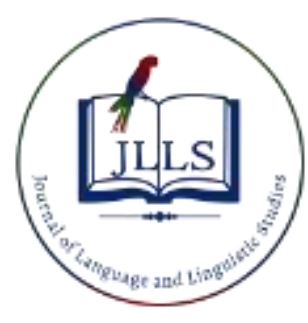

Available online at www.jlls.org

JOURNAL OF LANGUAGE

AND LINGUISTIC STUDIES

ISSN: $1305-578 \mathrm{X}$

Journal of Language and Linguistic Studies, 16(2), 896-911; 2020

\title{
An investigation into the relationship between willingness to communicate and classroom environment in a Turkish EFL context ${ }^{1}$
}

\author{
Merve Öksüz Zerey a 2 (D), Paşa Tevfik Cephe b ${ }^{\text {ID }}$ \\ ${ }^{a}$ Gazi University, Ankara, Turkey \\ ${ }^{b}$ Gazi University, Ankara, Turkey
}

APA Citation:

Öksüz-Zerey, M., \& Cephe, P. T. (2020). An investigation into the relationship between willingness to communicate and classroom environment in a Turkish EFL context. Journal of Language and Linguistic Studies, 16(2), 896-911.

Submission Date:19/01/2020

Acceptance Date:18/05/2020

\begin{abstract}
Theories of second/foreign language (L2) learning attach great significance to meaningful communication both inside and outside language classrooms. In this respect, it is vital that language learners use the target language. However, they substantially differ from one another with regard to how much they talk. This difference has been partly justified by willingness to communicate (WTC) in the second/foreign language. Over the past years, WTC and its relation with a number of social, personal and affective factors have been researched in various settings. Nonetheless, little research has been carried out to investigate L2 WTC in speaking inside the classrooms, specifically in Turkey. Besides, though language classrooms are the main platforms for the majority of learners, WTC has gone unnoticed in conjunction with classroom environmental factors thus far. Thus, this study aimed at investigating Turkish preparatory school students' WTC levels, their perceptions of language classrooms and the relationship between the two variables. In addition to that, gender differences were investigated to find out how male and female students differ in terms of their WTC and their perceptions of classroom environments. To these ends, two different questionnaires were employed. The results unraveled that the students were somewhat willing to communicate in English. Besides, regarding classroom environments, the students reported having positive perceptions. As for gender, females were found slightly more willing to communicate than their male counterparts; however, no significant difference was obtained concerning perceptions of classroom environments. Lastly, correlation analyses indicated that the level of L2 WTC was significantly and strongly related to the classroom environment. In other words, the more positively the students perceive their language classrooms, the more willing they are to communicate.
\end{abstract}

C 2020 JLLS and the Authors - Published by JLLS.

Keywords: willingness to communicate; classroom environment; L2 learning; language use; gender differences

\footnotetext{
1 This paper has been produced from the first author's MA thesis under the supervision of the second author.

2 Corresponding author. Tel.: +9-0312-202-8496

E-mail address: merveoksuz@gazi.edu.tr
} 


\section{Introduction}

The field of L2 learning and teaching has witnessed waxing and waning of numerous methods over the past century. Each of these methods has attempted to reveal the best and ultimate practices to achieve their goals. Since the 1980s, communicative methods have dominated the field and significantly changed the way an L2 is taught. Accordingly, communication in the target language lies at the heart of language learning, thereby forming the basis of language instruction.

Despite heavy emphasis on communication by contemporary language pedagogy, learning an L2 and communicating through it do not follow linear steps. On the contrary, it is a complex phenomenon that is greatly influenced by affective, personal and linguistic variables. One of those variables that is subject to research is willingness to communicate (WTC). Drawing on research on WTC in one's native language (L1), MacIntyre and Charos (1996) expanded the boundaries of the construct and WTC was applied to L2 contexts. Defined as "readiness to enter into discourse at a particular time with a specific person or persons, using a L2" (MacIntyre, Dörnyei, Clément, \& Noels, 1998, p. 547), L2 WTC is hypothesized to exert direct influence on L2 use (Hashimoto, 2012). To put it differently, a person's WTC can affect the extent to which he/she uses the target language.

Research on second language acquisition (SLA) supports that interaction in the target language and production of linguistic output lead to language development (Ellis, 1994; Swain, 2005). Given that L2 growth is a consequence of language use, it becomes pivotal to boost learners' WTC. Furthermore, MacIntyre, Dörnyei, Clément, and Noels (1998) asserted "a suitable goal of L2 learning is to increase WTC" (p. 558). However, as implied, not all learners are willing to perform a task and take part in communication. In this regard, the related literature suggests that a learner's WTC, thereby his/her engagement in communication, has been influenced by such variables as self-perceived communication competence (SPCC) (Öz, Demirezen, \& Pourfeiz, 2015), foreign language anxiety (FLA) (Alemi, Daftarifard, \& Pashmforoosh, 2011), age and gender (Donovan \& MacIntyre, 2004).

Nonetheless, in spite of extensive body of studies on WTC and variables related to it, little research has been carried out on L2 WTC in tandem with classroom environment. Students spend significant amount of time in classes to learn a language, specifically in countries where English is learned as a foreign language (EFL) (Peng \& Woodrow, 2010). In these classes, it is utmost importance that students get the opportunity to speak and participate in activities because they are mostly limited to classrooms in terms of interaction and communication.

A language classroom is a social environment in which a number of interrelating factors such as teacher support, student cohesiveness, and task orientation play pivotal roles in learning and teaching. These factors can exert influence on students' thoughts and actions. This strand of research also suggested that student learning is an outcome of classroom environment of high quality (Fraser, 1994). Accordingly, the sheer necessity for a positive classroom atmosphere is undeniable.

\subsection{Research questions}

Due to the crucial role that classroom dynamics play in L2 learning and scarcity of research on L2 WTC in conjunction with these dynamics, the present study sets out to unveil the relationship between L2 WTC and classroom environment. Besides, it aims at investigating gender differences with regard to L2 WTC and perceptions of classroom environments. To this end, it attempts to find answers to the following research questions:

1. How willing are Turkish Preparatory school students to communicate in English?

1.1. Is there a difference between male and female students in terms of their willingness to communicate in English? 
2. How do Turkish preparatory school students perceive their language classroom environments?

2.1. Is there a difference between male and female students in terms of their perceptions of classroom environment?

3. What is the relationship between students' willingness to communicate and their perceptions of the classroom environment?

\subsection{Literature review}

\subsubsection{Willingness to communicate in language learning}

Language is undeniably a fundamental tool for human beings through which they communicate, share feelings and ideas, exchange information, and establish networks. For the most part, it is oral communication, namely talk, that enables individuals to perform functions of a language. Upon the significance of talk, McCroskey and Richmond (1990) state that "without talk most interpersonal communication would have little reason to exist" (p. 19). Accordingly, it is expected that the degree, amount and quality of communication exert influence on the development of interpersonal relationships and the degree to which individuals understand each other.

McCroskey and Baer (1985) observed that people vary remarkably with regard to how much they talk. Some talk a lot, some mostly keep their silence and some talk under certain conditions. Grounded on the differences among people with respect to amount and frequency of language use, McCroskey and Baer (1985) put forward the concept of WTC in one's native language as a personality variable. Accordingly, it is this personality trait that demonstrates why under equal conditions one person would communicate while the other would not. Following the conceptualization of WTC, a number of studies were carried out to test it. This line of investigation into L1 WTC demonstrated that high willingness to communicate is likely to lead to more frequent language use (Chan \& McCroskey, 1987; MacIntyre, Babin, \& Clément, 1999; Zahaki \& McCroskey, 1989).

Upon the realization of WTC as a variable that affects the frequency of communication, MacIntye and Charos (1996) adapted the concept to L2 situations to find out whether WTC in L2 predicted the frequency of the target language use. By administering questionnaires to language learners, they revealed that WTC was an indicator of language output and it was affected by perceived competence and language anxiety. In their seminal work, MacIntyre et al. (1998) proposed the heuristic model of variables influencing WTC. According to the model, WTC is the most immediate factor that leads to L2 use, and it was defined as "a readiness to enter into discourse at a particular time with a specific person or persons, using a L2" (MacIntyre et al., 1998 p. 547). Besides, a number of interrelated personal, motivational, affective and cognitive factors were postulated to influence WTC and communication behavior. Simply put, WTC is subjected to the impact of several variables, and it is regarded as the ultimate step prior to overt language use.

Subsequent research provided evidence that L2 WTC and numerous variables are directly or indirectly intertwined. Of these, perceived communicative competence and foreign language anxiety were consistently found to be strong predictors of L2 WTC (Baker \& MacIntyre, 2000; Hashimoto, 2002; Lahuerta, 2014; Yashima, 2002; Yashima, Zenuk-Nishide, \& Shimizu, 2004). The findings of these studies suggest that as a learner's perception of what she/he can do with the language increases so does her/his WTC. On the other hand, anxiety is negatively correlated with WTC which means that the lower the level of anxiety, the higher the level of L2 WTC. In addition to these, research studies have demonstrated that higher L2 WTC is related to higher motivation (Jung, 2011; Peng, 2007), positive classroom environment (Khajavy, Ghonsooly \& Fatemi, 2016; Peng \& Woodrow, 2010, Riasati, 2012), teacher support (Peng, 2012), and extraversion (Alishah, 2015; Öz, 2014). Lastly, it has previously been 
observed that gender differences might exist concerning L2 WTC although research findings vary (Donovan \& MacIntyre, 2014; MacIntyre, Baker, Clément, \& Donovan, 2002; Öz, 2014).

MacIntyre, Baker, Clément, and Conrod (2001, p. 382) put forward that "using the language strongly implies a preexisting behavioral intention, a willingness to communicate in the L2". Considering that "talking in order to learn" (Skehan, 1989, p. 48) is a crucial aspect of the L2 learning process, it becomes essential that students talk. For this reason, they first need to be willing to communicate. In addition to the language use, Kang (2005) hypothesizes that when L2 WTC is enhanced, it also helps learners become more autonomous learners who are likely to attempt at learning the language without teachers' help and it leads learners to extend their learning opportunities. When these advantages are taken into consideration, it would be legitimate to advance that WTC is a crucial communication variable that warrants a closer inspection.

\subsubsection{Classroom environment and L2 WTC}

According to Crystal (2003), the number of non-native English speakers outnumbers native speakers. Though a significant number of these non-native speakers learn it in naturalistic settings, the bulk of people are exposed to English in instructed environments, namely classrooms. Put it broadly, a language classroom refers to

a place where a variety of participants with potentially differing perspectives on the nature and goals of language teaching meet and interact, which gives rise to a dynamic tension between their differing perceptions of the nature and goals of language teaching (Tudor, 2001, p. 43).

The significance of positive classroom atmosphere cannot be ignored provided that effective teaching and learning are targeted. Williams and Burden (2000) state "the immediate physical environment of the classroom and the nature of the personal interactions which occur within it will have a profound influence upon whether, what and how any individual learns a language" (p. 189). In other words, the role that classrooms play in learning is crucial.

Fraser, Fisher and McRobbie (1996) approached the classroom environment with the lens focused on psychosocial factors. Central to this approach are seven components that make up a classroom, which are student cohesiveness, teacher support, involvement, investigation, task orientation, cooperation, and equity. The first of these, student cohesiveness, is related to support, help and familiarity. Teacher support is about whether the teacher is helpful, interested in students and friendly. According to Dorman (2003, p. 234), involvement is "the extent to which students have attentive interest, participate in discussions, do additional work and enjoy the class." Likewise, investigation is related to problemsolving and researching skills. Task orientation is defined as "the extent to which it is important to complete activities planned and stay on the subject matter" (Dorman, 2003, p. 234). As can be gleaned from its name, cooperation is about how much students cooperate instead of competing. Lastly, equity is related to whether students think they are treated equally by their teacher or not. Since each of these contributes to learning when perceived positively, these seven dimensions of a classroom environment were taken into consideration in the present research.

In language classes, it is expected that students display willingness to communicate in the target language and participate in tasks actively because classrooms can be most of the time only platform for learning and using the language, specifically for English as a foreign language (EFL) learners who have little opportunities to interact in the L2 outside the classroom. For this reason, L2 WTC and use of the target language must be promoted in language classrooms. Therefore, a positive and supportive classroom climate is deemed pivotal. By investigating the relationship between WTC and classroom environment, teachers and students can negotiate and make arrangements to improve students' WTC. 
Previous research also provides evidence to the close link between WTC and classroom environment. Through self-report surveys, Peng and Woodrow (2010) and Khajavy, Ghonsooly and Fatemi (2016) unveiled that a positive classroom environment is a predictor of higher L2 WTC. Peng (2012) discovered that teacher support and meaningful interaction boosted students' WTC. Riasati (2012) carried out semistructured interviews with EFL learners and he found out that topic, teacher, atmosphere, and interlocutors influenced WTC. Zhong (2013) revealed learners were more willing in collaborative classrooms then they were in teacher-led classrooms. Kang's (2005) qualitative research indicated that interlocutors' higher social support, familiarity with them, and topics affected L2 WTC positively.

These studies demonstrate that classroom environmental factors exert influence on L2 WTC. However, there is still scant research into L2 WTC in conjunction with classroom environment. Considering that language classrooms constitute a crucial dimension of language learning, this line of investigation merits thorough examination. This study was undertaken to fill this gap in the literature with a focus on L2 WTC, classroom environment, and the relationship between the two as well as gender differences.

\section{Method}

For the purposes of the current research, a quantitative research design was adopted so that valid and objective descriptions could be made on phenomena (Taylor, 2005).

\subsection{Participants}

The participants in this study consisted of 296 preparatory school students enrolled at a state university. All the participants were all non-English majors and they were learning English as a foreign language. Of these, 130 were male and 136 were female. In participant selection, convenient sampling method was employed. Cohen and Manion (1994, p. 88) explain that "it involves choosing the nearest individuals to serve as respondents until the required sample size has been obtained". Accordingly, accessibility and availability of the participants during data collection were taken into consideration.

\subsection{Data collection and instruments}

For the purposes of the current research, two different questionnaires were employed in two phases. In the first phase, which is piloting, the questionnaires were administered to 165 students and 153 valid data were used for validity and reliability analyses following data screening. In the second phase, a total of 320 students responded to the questionnaires and 296 of them were obtained for further analysis. Below are the descriptions of the instruments and evidence concerning validity and reliability.

\subsubsection{Willingness to communicate}

Constructed by Weaver's (2005), L2 WTC in speaking scale involves 17 items that are designed to measure L2 WTC inside the classroom. Following a meticulous translation and adaptation process, the items were translated into Turkish.

As the questionnaire was adapted to Turkish, it became vital to verify construct validity, which is "the extent to which an operationalization measures the concept it is supposed to measure" (Bagozzi, Yi, \& Phillps, 1991, p. 421). To this end, the exploratory factor analysis (EFA) was carried out so that underlying factors with reference to relations among variables being measured could be identified (Büyüköztürk, 2002). Accordingly, as in the original questionnaire, one factor was extracted and the items with factor loadings lower than .30 were removed from the analysis one by one (Büyüköztürk, 
2014; Çokluk, Şekercioğlu, \& Büyüköztürk, 2014). Moreover, the remaining 15 items explained $35.866 \%$ of the variance of the questionnaire, which is adequate for one factor structure (Tavşancil, 2005). The EFA results suggest that the Turkish version of the L2 WTC in speaking scale has construct validity. Put it differently, it measures learners' L2 WTC inside language classrooms. With regard to reliability, statistical analysis yielded a score of .870, which is rather satisfactory (Büyüköztürk, 2014). This score shows that the instrument can be used in the current research safely.

Fifteen items in the Turkish version are rated on a four-point Likert scale as in the original format as Weaver (2005) considers that it helps to eliminate neutral responses ( $1=$ definitely not willing; $2=$ probably not willing; $3=$ probably willing; $4=$ definitely willing) (Appendix A).

\subsubsection{What is happening in this classroom (WIHIC)}

Initially devised by Fraser et al. (1996) to measure students' perceptions of classroom environment, the WIHIC questionnaire has been validated in a number of contexts (Aldridge \& Fraser, 2000; Chionh \& Fraser, 1998; Kim, Fisher, \& Fraser, 2000). In Turkey, Telli, Cakiroglu, and den Brok (2006) carried out the translation and validation process of the Turkish version of the questionnaire. Within the scope of the current research, a pilot study was carried out and internal consistency of the scales was calculated by using Cronbach's Alpha coefficients. They were found as the following: student cohesiveness ( 8 items, $\alpha=.85$ ), teacher support ( 8 items, $\alpha=.90$ ), involvement ( 8 items, $\alpha=.81$ ), investigation ( 8 items, $\alpha=.88$ ), task orientation ( 8 items, $\alpha=.83$ ), cooperation ( 8 items, $\alpha=.86$ ), equation ( 8 items, $\alpha=.91$ ), and overall (56 items, $\alpha=.94)$.

Accordingly, 56 items in seven subscales were assessed based on a five-point Likert scale ranging from $1=$ totally disagree to $5=$ totally agree.

\subsection{Data analysis}

Data collected by means of the questionnaires were computerized and then were analyzed via SPSS. Initially, descriptive statistics was performed to gain a clear understanding of the students' WTC levels and their perceptions of classroom environment. Secondly, independent-samples t-test was employed to reveal whether male and female differed significantly regarding both their L2 WTC and perceptions of classroom environments. After that, correlation coefficients were calculated to find out whether WTC and classroom environment were related and, if so, what the magnitude of that relationship was.

\section{Results and discussion}

\subsection{How willing are Turkish Preparatory school students to communicate in English?}

Table 1 demonstrates the descriptive statistics on L2 WTC inside the classroom. In the assessment of the mean scores, "(4-1) $/ 4=0.75$ " formula was used. The intervals are as follows: $1-1.75$ definitely not willing; 1.76-2.51 probably not willing; 2.52-3.27 probably willing; and 3.28-4.00 definitely willing. Accordingly, overall mean scores indicate that the students are probably willing to communicate in their classrooms. In addition to that, when the mean scores of each item are investigated, it is seen that the students' WTC fluctuates between probably not willing to probably willing depending on the language tasks. 
Table 1. Descriptive statistics on L2 WTC inside the classroom

\begin{tabular}{llllll}
\hline & $\mathrm{N}$ & Minimum & Maximum & Mean & Std. Deviation \\
WTC_MEAN & 296 & 1.00 & 3.93 & 2.5466 & .55080 \\
Valid N (listwise) & 296 & & & & \\
\hline
\end{tabular}

These findings obtained through the present research corroborates with those of which have been carried out both in Turkey and abroad. As in the present research, Çetinkaya (2005) found out that preparatory school students were somewhat willing to communicate in English. Likewise, Başöz and Erten (2018) demonstrated that EFL learners at a state university had a moderate level of WTC both inside and outside the classroom. On the other hand, studies carried out by Öz, Demirezen, and Pourfeiz (2015), Öz (2014), and Şener (2014) yielded more satisfactory levels of WTC. These higher mean scores with regard to the latter group can be attributed to the students' academic majors because they were English-major students who were being trained to be English teachers. It can be assumed that they are more proficient in English and this can exert influence on their WTC. With regard to studies conducted abroad, similar findings were reported as well. Hashimoto (2002) and Weaver (2005) reported moderate level of willingness to communicate in Japan and Korea respectively. This indicates that EFL students may display similar levels of WTC in English across countries.

Taken together, this line of research suggests that L2 WTC needs boosting to promote language use inside and outside the classroom around the world. Considering that English has been a lingua franca, a language of communication among speakers with different cultural, contextual and linguistic backgrounds and that competent English users have been in demand around the world, promoting language use and enhancing WTC can contribute to the education of competent language users.

\subsubsection{Is there a difference between male and female students in terms of their willingness to communicate in English?}

As shown in Table 2, the results of the independent-samples t-test revealed a significant difference between male and female students regarding their L2 WTC. Accordingly, females are slightly more willing to communicate in English than their male counterparts. Nonetheless, the size of the difference is quite small (eta squared=0.029). It means that gender accounts for only $0.29 \%$ of the variance in WTC. For this reason, it can be stated that gender differences explain, if any, a little variance in L2 WTC.

Table 2. Independent-samples t-test of genders

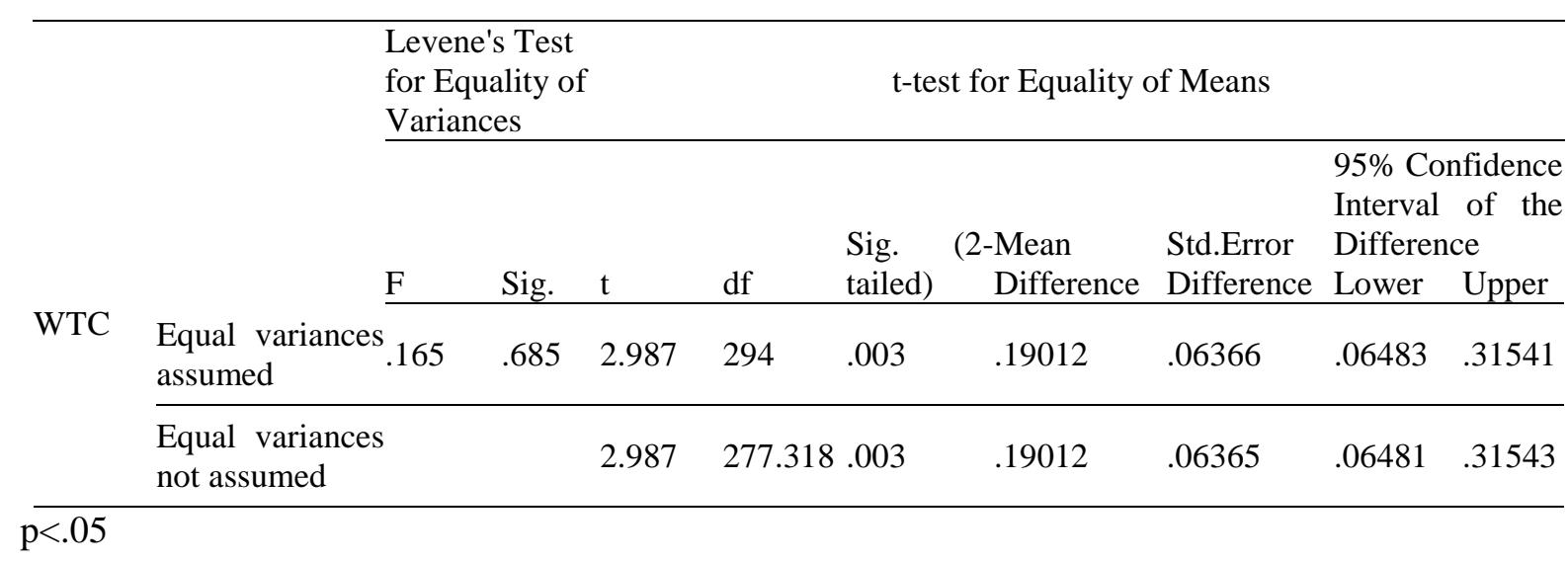

Despite significant but slight difference, this finding contrasts with Öz et al. (2014), Öz (2014) and Şener (2014), in which insignificant gender differences were found. This discrepancy can be attributed to the context of the study. While these studies researched WTC irrespective of the learning context, the 
present research specifically focused on L2 WTC inside the classrooms. Similarly, Baker and MacIntyre's (2000) research indicated that female students opted for L2 use in classrooms, while male students preferred out-of-class L2 communication. In this respect, though these findings imply a chance that the context in which an L2 is used leads to gender differences, this implication should be approached cautiously without further research.

\subsection{How do Turkish preparatory school students perceive their language classroom environments?}

The findings related to the students' perceptions of language classroom environments were tabulated below. In the assessment of the mean scores, "(5-1)/5 $=0.80$ " formula was used. The intervals are as follows: 1-1.80 never; 1.81-2.61 almost never; 2.62-3.42 sometimes; 3.43-4.24 almost always; and 4.255.00 always. Based on these criteria, descriptive statistics demonstrates that students perceive their classes almost always positively. As seen in the table, while the highest scores were obtained from equity, the lowest scores came from investigation.

Table 3. Students' Perceptions of Language Classroom Environments

\begin{tabular}{llllll}
\hline Descriptive Statistics & & & & & \\
& $\mathrm{N}$ & Minimum & Maximum & Mean & Std. Deviation \\
Student cohesiveness & 296 & 1.88 & 5.00 & 3.6014 & .61829 \\
Teacher support & 296 & 1.00 & 5.00 & 3.3725 & .83495 \\
Involvement & 296 & 1.88 & 9.25 & 3.4409 & .74397 \\
Investigation & 296 & 1.00 & 5.00 & 3.3391 & .77619 \\
Task orientation & 296 & 1.25 & 5.00 & 3.7238 & .66252 \\
Cooperation & 296 & 1.25 & 5.00 & 3.6588 & .72099 \\
Equity & 296 & 1.00 & 5.00 & 3.7542 & .78538 \\
Total & 296 & 2.29 & 4.96 & 3.5558 & .49518 \\
Valid N (listwise) & 296 & & & & \\
\hline
\end{tabular}

Williams and Burden (2000) state that "an important aspect of any investigation into classroom environment is the perceptions that learners have of the climate that prevails in their classrooms" ( $p$. 202). Students' perceptions were found to be positive and this finding is crucial in that better learning occurs when classroom environment is perceived positively (Dorman, Aldridge, \& Fraser, 2006). Additionally, Bucholz and Sheffler (2009) express that "the classroom environment should do as much to foster cooperation and acceptance as the teaching methods that the teacher uses" (p. 1). This study reveals that student cohesiveness and cooperation are boosted in language classrooms, contributing to a constructive learning atmosphere. Regarding equity, the students consider to be treated fairly. This is a dimension that is emphasized and deemed crucial in all walks of life. In this sense, it can be stated that the teachers could achieve creating a democratic classroom. On the other hand, the mean scores of teacher support indicate that students sometimes get support from their teachers. The related literature demonstrates the significance of teacher support for learning. To illustrate, Hallinan (2008) found that respect and praise from teachers affect how much students like schools. A sense of belonging among students could be nurtured through teacher support, thereby leading to better learning. In this respect, increasing the amount of teacher support can give rise to establishment of a positive classroom environment, which brings many other benefits. 
3.2.1. Is there a difference between male and female students in terms of their perceptions of classroom environment?

Although female students scored higher than male students in the questionnaire, independentsamples t-test did not yield a significant gender difference. For this reason, it can be argued that they have similar perceptions of their classroom environments.

A possible explanation for insignificant gender differences can be that both genders are treated equally in classes, they have the same opportunities to learn, talk and contribute to classroom learning without gender discrimination. It is an expected and desired outcome of the current educational policies.

Table 4. Independent-samples of t-test of genders

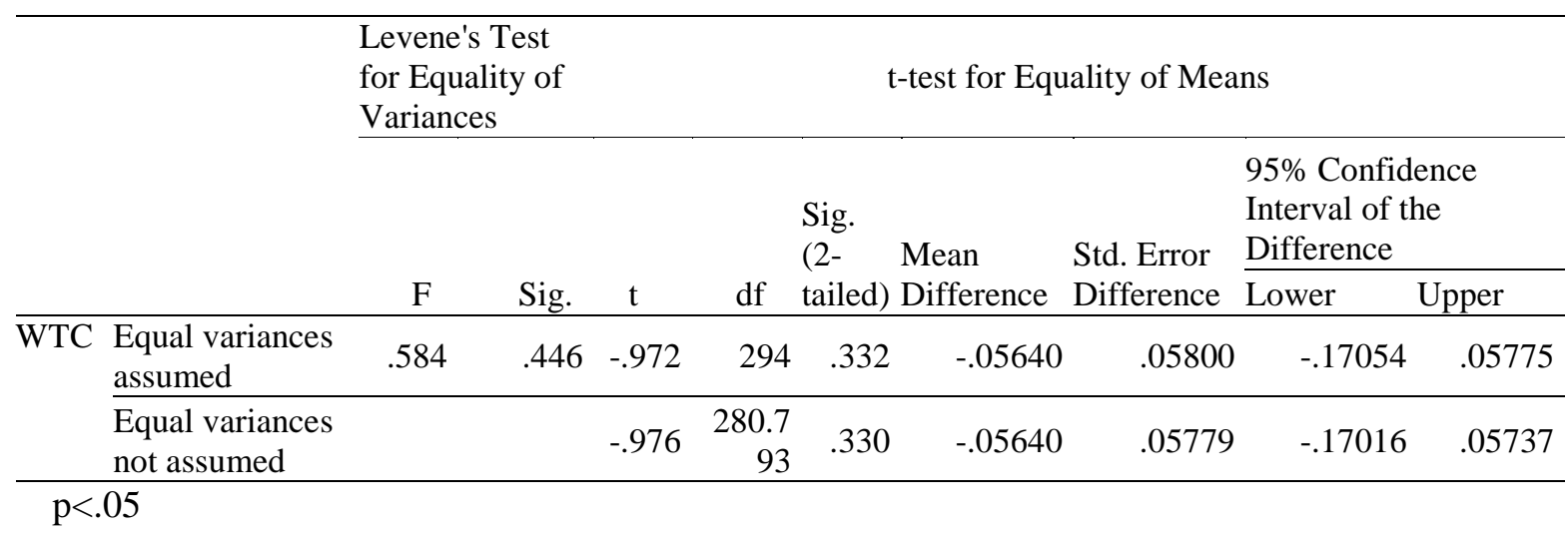

3.3. What is the relationship between students' willingness to communicate and their perceptions of the classroom environment?

In order to reveal the relationship between L2 WTC and classroom environment, Pearson correlation analysis was performed and the findings are presented in Table 3. Field (2013) specifies the effect sizes of the correlation coefficients ( $r$ ) as follows: $r=.10$ small effect size, $r=.30$ medium effect size and $r=.50$ large effect size. Based on these guidelines and significance values, the overall findings indicate that students' WTC is significantly and strongly related to their perception of classroom environment. Put it differently, the more positively the students perceive their classes, the more willing they are to communicate in English.

Table 5. Correlations between L2 WTC and classroom environment

Correlations

\begin{tabular}{|c|c|c|c|c|c|c|c|}
\hline 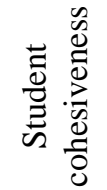 & 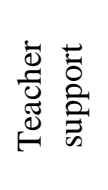 & $\begin{array}{l}\overrightarrow{0} \\
0 \\
0 \\
0 \\
0 \\
0\end{array}$ & 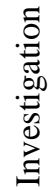 & 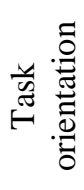 & 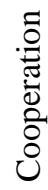 & 悹 & $\stackrel{\underline{\Xi}}{\stackrel{\Xi}{\Xi}}$ \\
\hline
\end{tabular}

\begin{tabular}{|c|c|c|c|c|c|c|c|c|c|}
\hline $\begin{array}{l}\text { WTC } \\
\text { MEAN }\end{array}$ & Pearson Correlation & $.304^{* *}$ & $.244^{* *}$ & $.386^{* *}$ & $.381^{* *}$ & $.445^{* *}$ & $.384^{* *}$ & $.347^{* *}$ & $.525^{* *}$ \\
\hline & Sig.(2-tailed) & .000 & .000 & .000 & .000 & .000 & .000 & .000 & .000 \\
\hline & $\mathrm{N}$ & 296 & 296 & 296 & 296 & 296 & 296 & 296 & 296 \\
\hline
\end{tabular}

**. Correlation is significant at 0.01 level (2-tailed).

This positive and significant relationship has been put forward by few research studies as well. Peng and Woodrow (2010), Peng (2012) and Khajavy et al. (2016), Riasati (2012) suggested that classroom 
environment is a crucial predictor of L2 WTC. Besides, as can be gleaned from the table, all the subdimensions of the classroom environment are significantly related to L2 willingness to communicate. Of these, task orientation and WTC has the highest correlation coefficients, suggesting that the more the students study to succeed, the more attention they pay to the subject matter, the more they are aware of the goals of the course, and the more willing they are likely to be in the classroom.

The link between teacher support and L2 WTC indicates that though the relationship between the two is significant, the magnitude of the relationship is weak. Though teacher support is slightly related to L2 WTC in this research, influence of teacher support on L2 WTC has been emphasized in the related literature. To illustrate, Riasati (2012) found that dictator-type teachers caused students to become unwilling to communicate. On the other hand, Both Pattapong (2013) and Tan, Yough and Wang (2018) unveiled that support, encouragement and speaking opportunities provided by teachers helped learners enhance their WTC.

Cooperation appears to be significantly linked to L2 WTC with a medium effect size, suggesting that as students cooperate rather than compete, they tend to become more willing communicators. In a similar vein, Cao (2013) demonstrated that the students were unwilling to talk to uncooperative group members. Likewise, in Zhong's (2013) research, teacher-led and collaborative learning contexts were investigated in terms of L2 WTC and the students were found to be more willing to communicate in collaborative learning environments. Johnson and Johnson (2008, p. 29) remark "research has showed that having students engage in cooperative learning results in higher achievement, greater retention, more positive feelings by the students about each other and the subject matter, and stronger academic self-esteem, compared to competitive and individualistic learning." This explanation indicates that a cooperative learning environment brings substantial individual and academic gains on the part of the learners. In this sense, it seems cooperation should be boosted in classes and, in return, L2 WTC is highly likely to improve.

Equity and L2 WTC are related to each other significantly. It means when students feel equal treatment, they appear to be more willing to communicate. Similarly, both Pattapong (2013) and Riasati (2012) indicated that when equal attention is paid by teachers and equal opportunities are provided by them, the students display more willingness to communicate.

Student cohesiveness refers to how well students know each other, how well they work together and how much they support one another. The results obtained through this research indicate that student cohesiveness and WTC are related significantly, with a medium effect size. This is in line with the findings of the previous research. Both Riasati (2012) and Cao (2013) found out that students felt more willing to communicate when they talked to those who they already knew. In a similar way, Kang's (2005) study demonstrated unfamiliar interlocutors caused learners to be reluctant to speak. Cao and Philp (2006) summarize the issue "the more distant the relationship of the individual to the receiver(s), the less willing the individual is to communicate" (p. 488).

The analysis demonstrates a significant relationship between involvement and WTC with a medium effect size. It suggests that when students are interested and involved in tasks, when they participate actively in the class and enjoy it, they tend to become more willing communicators. Likewise, Cao (2013) unraveled that students' engagement with a task seemed to improve their WTC. In addition, Zarrinabadi (2014) remarked that student displayed more willingness to communicate when they had the chance to select the topic of discussion.

Lastly, investigation and WTC were found to be strongly related to each other. It means the more students conduct investigations to answer questions, attempt at inquiring problems and solving them, the more willing they can become. To the best of the researchers' knowledge, there is not a research 
study examining the relationship between the two variables. In this sense, this study provides evidence concerning their relatedness, which merits more attention in future research.

\section{Conclusions}

The current research set out to probe how willing Turkish preparatory school students were to speak English in their classes, how they perceived their language classroom environments, and how related these two constructs were. Accordingly, quantitative data were collected from preparatory students at a state university through validated and reliable instruments.

Crucial pedagogical implications have arisen in accordance with the findings of this research. First of all, the students were found to be probably willing to communicate in English inside their classrooms. However, the related literature puts forward that higher willingness to communicate results in more frequent use of the target language. For this reason, students' WTC needs to be boosted and their speaking in the class should be bolstered. Secondly, the significance and the magnitude of the relationship between WTC and perceptions of classroom environment indicates that the more positively students perceive their classrooms, the more willing they tend to be. Grounded on these findings, certain helpful suggestions can be offered. Initially, through a sense of trust and friendship, cohesiveness can be amplified among students. Besides, it should be cooperation rather than competition that is promoted in class. Students' active involvement in classes should be promoted by means of interesting and relevant activities. Moreover, while involving students, the teacher should behave equally, provide equal opportunities for each student to speak, ask, and answer questions. In addition to that, teacher support can contribute to students' WTC. For this reason, teachers should promote students' efforts and show interest in their learning. All in all, a supportive and positive classroom atmosphere can be created by taking these suggestions into consideration, which, in turn, leads to higher willingness to communicate and use of the target language inside the classrooms. Last but not least, the ultimate goal is to help learners become proficient and fluent L2 speakers irrespective of social contexts.

A number of caveats need to be noted concerning the current study. First of all, since the data were collected from a state university, further generalizations should be treated with caution. Secondly, this investigation aimed to cast light on the relationship between L2 WTC and dimensions of classroom environment by means of correlation method, and the results yielded neither in-depth data nor causeeffect relations. However, the study provided evidence that L2 WTC is strongly related to classroom environmental factors. For these reasons, further studies may investigate how these factors affect L2 WTC by employing various data collection techniques from different settings.

\section{Ethics Committee Approval}

The author(s) confirm(s) that the study does not need ethics committee approval according to the research integrity rules in their country. (Date of Confirmation: June 9, 2020)

\section{References}

Aldridge, J., \& Fraser, B. (2000). A cross-cultural study of classroom learning environments in Australia and Taiwan. Learning Environments Research, 3(2), 101-134.

Alemi, M., Daftarifard, P., \& Pashmforoosh, R. (2011). The impact of language anxiety and language proficiency on WTC in EFL context. Cross-Cultural Communication, 7(3), 150-166. 
Alishah, A. R. (2015). A study of factors affecting Turkish EFL learners' willingness to speak in English (Doctoral dissertation). Retrieved from https://tez.yok.gov.tr

Bagozzi, R. P., Yi, Y., \& Phillips, L. W. (1991). Assessing construct validity in organizational research. Administrative Science Quarterly, 36(3), 421-458.

Baker, S. C., \& MacIntyre, P. D. (2000). The role of gender and immersion in communication and second language orientations. Language Learning, 50(2), 311-341.

Başöz, T. \& Erten, İ. H. (2018). Investigating tertiary level EFL learners' WTC in English. English Language Teaching, 11(3), 78-87.

Bucholz, J. L. \& Sheffler, J. L. (2009). Creating a warm and inclusive classroom environment. Planning for all children to feel welcome. Electronic Journal for Inclusive Education, 2(4), 1-13.

Büyüköztürk, Ş. (2002). Faktör analizi: Temel kavramlar ve ölçek geliştirmede kullanımı. Kuram ve Uygulamada Ĕ̈itim Yönetimi, 32, 470-483.

Büyüköztürk, Ş. (2014). Sosyal bilimler için veri analizi el kitabı (19th ed.). Ankara: Pegem Akademi.

Cao, Y. (2013). Exploring dynamism in willingness to communicate: A longitudinal case study. Australian Review of Applied Linguistics, 36(2), 160-176.

Cao, Y., \& Philp, J. (2006). Interactional context and willingness to communicate: A comparison of behavior in whole class, group and dyadic interaction. System, 34(4), 480-493.

Cetinkaya, Y. B. (2005). Turkish college students' willingness to communicate in English as a foreign language (Doctoral dissertation). Retrieved from https://tez.yok.gov.tr

Chan, B., \& McCroskey, J. C. (1987). The WTC scale as a predictor of classroom participation. Communication Research Reports, 4(2), 47-50.

Chionh, Y. H., \& Fraser, B. J. (1998, April). Validation and use of the 'What is Happening in this Class'(WIHIC) questionnaire in Singapore. Paper presented at the Annual Meeting of the American Educational Research Association, San Diego, CA.

Cohen, L., \& Manion, L. (1994). Research methods in education (4th ed.). London: Routledge.

Crystal, D. (2003). English as a Global Language (2nd ed.). Cambridge: Cambridge University Press.

Çokluk, Ö., Şekercioğlu, G., \& Büyüköztürk, Ş. (2014). Sosyal bilimler için çok değişkenli istatistik: SPSS ve LISREL uygulamaları (3rd ed.). Ankara: Pegem Akademi.

Donovan, L. A., \& MacIntyre, P. D. (2004). Age and sex differences in willingness to communicate, communication apprehension, and self-perceived competence. Communication Research Reports, 21(4), 420-427.

Dorman, J. P. (2003). Cross-national validation of the What Is Happening in this Class? (WIHIC) questionnaire using confirmatory factor analysis. Learning Environments Research, 6(3), 231-245.

Dorman, J. P., Aldridge, J. M., \& Fraser, B. J. (2006). Using students' assessment of classroom environment to develop a typology of secondary school classrooms. International Education Journal, 7(7), 906-915.

Ellis, R. (1994). Implicit and explicit language learning-An overview. In N. Ellis (Ed.), Implicit and explicit learning of languages (pp. 1-31). London: Academic Press

Field, A. (2013). Discovering statistics using IBM SPSS statistics (4th ed.). Los Angeles: Sage. 
Fraser, B. J. (1994). Research on classroom and school climate. In D. Gabel (Ed.), Handbook of research on science teaching and learning (pp. 493-541). New York: Macmillan.

Fraser, B. J., Fisher, D. L., \& McRobbie, C. J. (1996, April). Development, validation and use of personal and class forms of a new classroom environment instrument. Paper presented at the annual meeting of the American Educational Research Association, New York, USA.

Hallinan, M. T. (2008). Teacher influences on students' attachment to school. Sociology of Education, $81(3), 271-283$.

Hashimoto, Y. (2002). Motivation and willingness to communicate as predictors of reported L2 use: The Japanese ESL context. Second Language Studies, 20(2), 29-70.

Johnson, R. T., \& Johnson, D. W. (2008). Active learning: Cooperation in the classroom. The Annual Report of Educational Psychology in Japan, 47, 29-30.

Jung, M. (2011). Korean EFL university students' willingness to communicate in English (Doctoral dissertation). Retrieved from http://www.proquest.com/products-services/pqdtglobal.html

Lahuerta, A. C. (2014). Factors affecting willingness to communicate in a Spanish university context. International Journal of English Studies, 14(2), 39-55.

Kang, S. J. (2005). Dynamic emergence of situational willingness to communicate in a second language. System, 33(2), 277-292.

Khajavi, G. H., Ghonsooly, B., Fatemi, A. H., \& Choi, C. W. (2016). Willingness to communicate in English: A microsystem model in the Iranian EFL classroom context. TESOL Quarterly, 50(1), 154180.

Kim, H. B., Fisher, D. L., \& Fraser, B. J. (2000). Classroom environment and teacher interpersonal behaviour in secondary science classes in Korea. Evaluation \& Research in Education, 14(1), 3-22.

MacIntyre, P. D., Babin, P. A., \& Clément, R. (1999). Willingness to communicate: Antecedents \& consequences. Communication Quarterly, 47(2), 215-229.

MacIntyre, P. D., Baker, S. C., Clément, R., \& Conrod, S. (2001). Willingness to communicate, social support, and language-learning orientations of immersion students. Studies in Second Language Acquisition, 23(03), 369-388.

MacIntyre, P. D., Baker, S. C., Clément, \& Donovan, L. A. (2002). Sex and age effects on willingness to communicate, anxiety, perceived competence, and L2 motivation among junior high school French immersion students. Language Learning, 52(3), 537-564.

MacIntyre, P. D., \& Charos, C. (1996). Personality, attitudes, and affect as predictors of second language communication. Journal of Language and Social Psychology, 15(1), 3-26.

MacIntyre, P. D., Dörnyei, Z., Clément, R., \& Noels, K. A. (1998). Conceptualizing willingness to communicate in a L2: A situational model of L2 confidence and affiliation. The Modern Language Journal, 82(4), 545-562.

McCroskey, J. C., \& Baer, J. E. (1985, November). Willingness to communicate: The construct and its measurement. Paper presented at the Annual Convention of the Speech Communication Association, Denver, CO.

McCroskey, J. C., \& Richmond, V. P. (1990). Willingness to communicate: A cognitive view. Journal of Social Behavior and Personality, 5(2), 19-37. 
Öz, H. (2014). Big Five personality traits and willingness to communicate among foreign language learners in Turkey. Social Behavior and Personality, 42(9), 1473-1482.

Öz, H., Demirezen, M., \& Pourfeiz, J. (2015). Willingness to communicate of EFL learners in Turkish context. Learning and Individual Differences, 37, 269-275.

Pattapong, K. (2010) Willingness to communicate in a second language: A qualitative study of issues affecting Thai EFL learners from students' and teachers' points of view (Doctoral dissertation). Retrieved from http://www.proquest.com/products-services/pqdtglobal.html

Peng, J. E. (2007). Willingness to communicate in an L2 and integrative motivation among college students in an intensive English language program in China. University of Sydney Papers in TESOL, 2(1), 33-59.

Peng, J. E. (2012). Towards an ecological understanding of willingness to communicate in EFL classrooms in China. System, 40(2), 203-213.

Peng, J. E., \& Woodrow, L. (2010). Willingness to communicate in English: A model in the Chinese EFL classroom context. Language Learning, 60(4), 834-876.

Riasati, M. J. (2012). EFL learners' perception of factors influencing willingness to speak English in language classrooms: A qualitative study. World Applied Sciences Journal, 17(10), 1287-1297.

Skehan, P. (1989). Individual differences in second language learning. London: Edward Arnold.

Swain, M. (2005). The output hypothesis: Theory and research. In E. Hinkel (Ed.), Handbook of research in second language teaching and learning (pp. 471-483). Mahwah, N.J.: L. Erlbaum Associates.

Şener, S. (2014). Willingness to communicate in English as a foreign language among ELT students in Turkey (Doctoral dissertation) Retrieved from http://tez.yok.gov.tr

Tan, D., Yough, M., \& Wang, C. (2018). International students in higher education: Promoting their willingness to communicate in classrooms. Journal of Applied Research in Higher Education, 10(4), 430-442.

Tavşancıl, E. (2005). Tutumların ölçülmesi ve SPSS ile veri analizi. Ankara: Nobel.

Taylor, G. R. (2005). Integrating quantitative and qualitative methods in research (2nd ed.). The USA: University Press of America.

Telli, S., Cakiroglu, J., \& den Brok, P. (2006). Turkish secondary education students' perceptions of their classroom learning environment and their attitude towards biology. In D. Fisher \& M. S. Khine (Eds.), Contemporary approaches to research on learning environments: Worldviews (pp. 517-542). Singapore: World Scientific.

Tudor, I. (2001). The dynamics of the language classroom. Germany: Ernst Klett Sprachen.

Weaver, C. (2005). Using the Rasch model to develop a measure of second language learners' willingness to communicate within a language classroom. Journal of Applied Measurement, 6(4), 396-415.

Williams, M. \& Burden, R. L. (1997). Psychology for language teachers: A social constructivist approach. Cambridge: Cambridge University Press.

Yashima, T. (2002). Willingness to communicate in a second language: The Japanese EFL context. The Modern Language Journal, 86(1), 54-66. 
Yashima, T., Zenuk-Nishide, L., \& Shimizu, K. (2004). The influence of attitudes and effect on willingness to communicate and second language communication. Language Learning, 54(1), 119152.

Zakahi, W. R., \& McCroskey, J. C. (1989). Willingness to communicate: A potential confounding variable in communication research. Communication Reports, 2(2), 96-104.

Zarrinabadi, N. (2014). Communicating in a second language: Investigating the effect of teacher on learners' willingness to communicate. System, 42, 288-295.

Zhong, Q. M. (2013). Understanding Chinese learners' willingness to communicate in a New Zealand ESL classroom: A multiple case study drawing on the theory of planned behavior. System, 41(3), 740-751.

\section{Appendix A. The L2 WTC questionnaire}

İngilizce sınıfımda;

1. Oturduğum yerden (sıramda) İngilizce bir drama etkinliğine katılırım. (örn. bir lokantada yemek siparişi vermek)

2. Elimdeki notlarla memleketim hakkında İngilizce kısa bir konuşma yaparım.

3. Sınıf arkadaşımı İngilizce selamlarım.

4. Ders kitabındaki İngilizce bir diyalogu sesli okurum.

5. Sınıfın önünde İngilizce bir drama etkinliğine katılırım. (örn. bir lokantada yemek siparişi vermek)

6. İngilizce bir kelimenin telaffuzunu İngilizce olarak sınıf arkadaşıma sorarım.

7. İzlediğim bir televizyon programını İngilizce olarak sınıf arkadaşıma anlatırım.

8. İngilizcesini bilmediğim bir ifadenin nasıl söyleneceğini İngilizce olarak sınıf arkadaşıma sorarım.

9. Ders kitabındaki soruları kullanarak sınıf arkadaşımla İngilizce görüşme yaparım.

10. Hazırladığım soruları kullanarak sınıf arkadaşımla İngilizce görüşme yaparım.

11. Kalemini bana ödünç verdiğinde sınıf arkadaşıma İngilizce teşekkür ederim.

12. Bilmediğim bir kelimenin anlamını İngilizce olarak sorarım.

13. En sevdiğim lokantanın yolunu İngilizce olarak tarif ederim.

14. Notlarıma bakmadan İngilizce olarak kısa bir biçimde kendimi tanıtırım.

15. Sözlü bir ifadeyi Türkçeden İngilizceye çeviririm. 


\section{İngilizce'yi yabancı dil olarak öğrenin Türk öğrencilerinin iletişim istekliliği ve sınıf iklimi algısı arasındasındaki ilişkinin incelenmesi}

\section{$\ddot{O} z$}

İkinci/yabancı dil öğrenim teorileri hem sınıfta hem de sınıf dışında dilin iletişim işlevine büyük önem atfeder. $\mathrm{Bu}$ anlamda, öğrenenlerin hedef dili kullanması oldukça önemlidir. Fakat öğrenenler birbirlerinden konuşma miktarları bakımından büyük ölçüde farklılık gösterirler. Bu faklılık kısmen ikinci dilde iletişim istekliliği ile açıklanmaktadır. İletişim istekliliği ve onun sosyal, kişisel ve duyuşsal etkenlerle ilişkisi geçtiğimiz yıllar boyunca çeşitli bağlamlarda araştırılmıştır. Ancak çok az çalışma ikinci dilde iletişim istekliliğinin sınıf içinde konuşma boyutuna odaklanmıştır. Bununla birlikte çoğu öğrenci için dil sınıfları temel öğrenme ortamları olmasına rağmen iletişim istekliliğinin sınıf iklimini oluşturan faktörlerle ilişkisi şimdiye kadar üzerinde durulan bir konu olmamıştır. Bu sebeple bu çalışma hazırlık okulu öğrencilerinin iletişim istekliliği seviyelerini, sınıf iklimi algılarını, ve bu iki değişken arasındaki ilişkiyi incelemeyi amaçlamaktadır. Cinsiyet farklılıkları da erkek ve kadın öğrencilerin iletişim istekliliği ve sınıf iklimi algılarının nasıl değişiklik gösterdiğinin bulunması amacıyla araştırılmıştır. Bu amaçlar doğrultusunda iki farklı anket kullanılmıştır. Sonuçlar öğrencilerin İngilizce iletişim kurma noktasında bir miktar istekli olduğunu göstermektedir. Sınıf iklimi boyutunda ise öğrencilerin algılarının olumlu olduğu görülmektedir. Cinsiyet açısından ise sonuçlar etki boyutu az da olsa kadınların erkeklerden İngilizce konuşmaya daha istekli olduğunu göstermektedir. Sınıf iklimi algısı boyutunda ise kadınlar ve erkekler arasında böyle bir farklılık bulunmamıştır. Son olarak, korelasyon analizi İngilizcede iletiş̧im istekliliği seviyesinin sınıf iklimi algısıyla anlamlı ve güçlü bir şekilde ilişkili olduğunu ortaya koymuştur. Diğer bir deyişle, öğrenciler sınıf ortamlarını daha olumlu bir şekilde algıladıkça İngilizce konuşmaya daha fazla istekli olacaklardır.

Anahtar sözcükler: iletişim istekliliği; sınıf iklimi, ikinci dil eğitimi; ikinci dil kullanımı; cinsiyet farklılıkları

\section{AUTHOR BIODATA}

Merve Öksüz Zerey works as a research assistant at Gazi University, ELT Program. Currently, she is a PhD candidate. Her research interests center around second language acquisition and teacher education.

Paşa Tevfik Cephe is a professor of English Language Teaching at Gazi University. His research studies, presentations and publications have addressed numerous aspects of teacher training and teaching language skills. 